\title{
Study of Association of Serum Uric Acid Level with Severity of Essential Hypertension
}

\author{
S. Moorthy ${ }^{1}$, G. Premkumar ${ }^{2}$ \\ ${ }^{1}$ Postgraduate, Department of General Medicine, SMVMCH, Puducherry \\ ${ }^{2}$ Associate Professor, Department of General Medicine, SMVMCH, Puducherry \\ Corresponding Author: S. Moorthy
}

DOI: https://doi.org/10.52403/ijrr.20220260

\begin{abstract}
Hypertension is one of the leading causes of the global burden of disease. Hyperuricemia is present in $25-50 \%$ of individuals with untreated primary hypertension, about 5 times the frequency found in normotensive persons. Raised serum uric acid concentrations in the blood are commonly encountered in essential hypertension. The hyperuricemia observed in untreated hypertension may reflect the decrease in renal blood flow and early hypertensive nephrosclerosis. Hence it is important to associate the serum uric acid level and the severity of hypertension and to find whether serum uric acid can be used as a useful tool to assess the severity of hypertension
\end{abstract}

Key Words: Hypertension, Serum Uric Acid

\section{INTRODUCTION}

Hypertension is one of the leading causes of the global burden of disease. Although antihypertensive therapy reduces the risks of cardiovascular and renal disease, large segments of the hypertensive population are either untreated or inadequately treated. Hyperuricemia is present in $25-50 \%$ of individuals with untreated primary hypertension, about 5 times the frequency found in normotensive persons. Raised serum uric acid concentrations in the blood are commonly encountered in essential hypertension. The hyperuricemia observed in untreated hypertension may reflect the decrease in renal blood flow and early hypertensive nephrosclerosis

\section{AIM AND OBJECTIVES}

To associate the serum uric acid level with the severity of hypertension among people aged between 30 and 60 years of age

\section{METHODOLOGY}

The study was a hospital based cross sectional study done under the Department of General Medicine at Sri Manakula Vinayagar Medical College and Hospital (SMVMCH), Puducherry. The patients were classified into the various stages of hypertension as per the JNC-7. Hypertensive patients attending outpatient/ inpatient Department of General Medicine was included for the study. Patients above 18 years of age, newly diagnosed patients of essential hypertension, Patients with essential hypertension on treatment are included in the study. Patients with renal failure, Patients on treatment with drugs altering uric acid levels such as thiazides, loop diuretics, pyrazinamide and allopurinol, Lymphoproliferative or myeloproliferative disorders were excluded from the study.

Sample size was calculated as 96 and after identifying patients with hypertension, appropriate questionnaire was used to collect details of the patient and detailed clinical examination was done and average blood pressure was measured. 
Analysis was done by estimating the and blood pressure severity. association between serum uric acid level

\section{RESULTS}

\begin{tabular}{|l|l|l|l|l|l|}
\hline & \multicolumn{2}{|l|}{ Hypertension category } & \multirow{2}{*}{ p value* } \\
\cline { 2 - 5 } & Normal & Pre-hypertension & Stage 1 hypertension & Stage 2 hypertension & \\
\hline $\begin{array}{l}\text { Serum Uric acid levels, } \\
\text { Mean }( \pm \text { SD) }\end{array}$ & $3.2( \pm 0.7)$ & $3.3( \pm 1.1)$ & $5.1( \pm 1.3)$ & $7.7( \pm 2.1)$ & $<\mathbf{0 . 0 0 1}$ \\
\hline
\end{tabular}

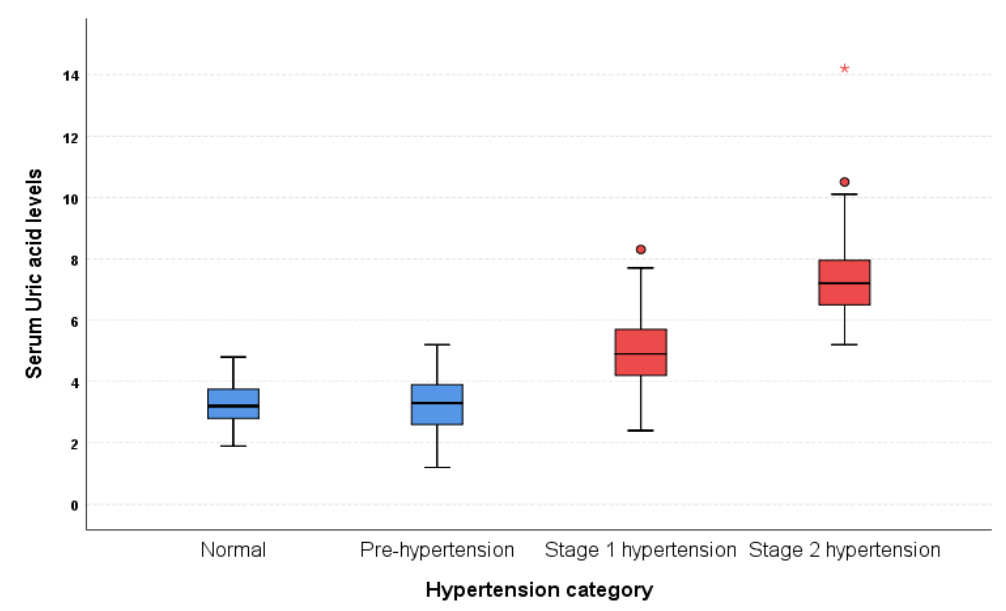

The serum uric acid levels were significantly higher in patients with stage I and stage II hypertension on comparison with normotensive patients. $(\mathrm{p}<0.05)$

\begin{tabular}{|l|l|l|l|}
\hline & $\begin{array}{l}\text { Normal/ } \\
\text { Prehypertensive } \\
(\mathbf{n}=)\end{array}$ & $\begin{array}{l}\text { Hypertension } \\
(\mathbf{n}=)\end{array}$ & $\begin{array}{l}\mathbf{p} \\
\text { value* }\end{array}$ \\
\hline $\begin{array}{l}\text { Uric acid } \\
\text { levels, } \\
\text { Mean }( \pm \text { SD) }\end{array}$ & $3.3( \pm 0.9)$ & $6.0( \pm 2.1)$ & $<\mathbf{0 . 0 0 1}$ \\
\hline
\end{tabular}

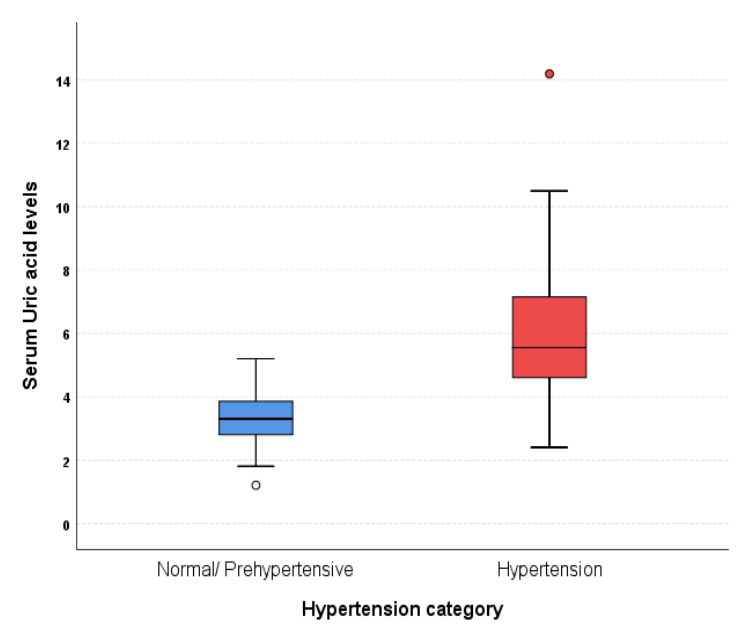

The serum uric acid levels were significantly higher in patients with hypertension on comparison with normotensive patients. $(\mathrm{p}<0.05)$

\section{DISCUSSION}

In the present study, the mean age of the patients was $50.2( \pm 8.7)$ years. Majority of the patients were in the age group of 5160 years $(56 \%)$ and were males $(62 \%)$. About $34 \%$ and $20 \%$ of the patients had stage I and stage II hypertension respectively. More than one-fourth (28\%) had diabetes mellitus. The mean serum uric acid levels was $4.8( \pm 2.1) \mathrm{mg} / \mathrm{dL}$. About $17 \%$ of the patients had high serum uric acid levels. The mean serum uric acid level in normotensive patients is $3.2( \pm 0.7)$ and prehypertensive patients is $3.3( \pm 1.1)$ and stage 1 hypertensive patients is $5.1( \pm 1.3)$ and stage 2 hypertensive patients is 7.7 $( \pm 2.1)$. Data analysis by one-way ANOVA with $\mathrm{p}$ value <.001. The mean serum uric acid in the hypertensive group was 6.0 $( \pm 2.1) \mathrm{mg} / \mathrm{dl}$. On the other hand, the mean serum uric acid level was $3.3( \pm 0.9) \mathrm{mg} / \mathrm{dl}$ in normal/ prehypertensive group, data analysis by independent $t$ test with $p$ value $<.001$. There is a significant positive 
correlation between systolic blood pressure and serum uric acid levels $(\mathrm{p}<0.05)$ with a $\mathrm{r}$ value of 0.828 . There is a significant positive correlation between diastolic blood pressure and serum uric acid levels $(\mathrm{p}<0.05)$ with a $r$ value of 0.605

\section{CONCLUSION}

Serum uric acid was significantly raised in patients with uncontrolled hypertension than in patients with controlled hypertension.

Hence serum uric acid levels can be used as an independent marker for finding the severity and early detection of complications of hypertension.

Acknowledgement: None

Conflict of Interest: None

Source of Funding: None

Ethical Approval: Approved

\section{REFERENCES}

1. Kasper DL, Hauser SL, Jameson JL, Fauci AS, Longo DL, Loscalzo J. Harrison's principle of internal medicine. 20th Ed. New York: The McGraw-Hill Companies; 2018.

2. Parveen M, Sinha RM. Assessment of serum uric acid in patients suffered from essential hypertension. Int $\mathrm{J}$ Med Health Res 2018;4(10):215-17.

3. Reddy RP, Monigari N, Hande M. Study of Serum Uric Acid in Essential Hypertension. Int J Sci Res 2015;5(8):112.

4. Verdecchia P, Schillaci G, Reboldi G, Santeusanio F, Porcellati C, Brunetti P. Relation between serum uric acid and risk of cardiovascular disease in essential hypertension. J Am Heart Assoc. 2000;36:1072-78

How to cite this article: S. Moorthy, G. Premkumar. Study of association of serum uric acid level with severity of essential hypertension. International Journal of Research and Review. 2022; 9(2): 476-478. DOI: https://doi.org/10.52403/ijrr.20220260 